\title{
ホルモン補充療法による閉経後女性の動脈硬化, 皮膚の弾力性及び骨密度への影響
}

\author{
——経皮エストラジオールと経口結合型エストロゲンとの比較
}

\author{
角 野 博 之, ${ }^{1}$ 市 川 秀 一, ${ }^{2}$ 坂 本 浩之助 ${ }^{3}$ \\ 村 上 正 巳, ${ }^{4}$ 酒 巻 哲 夫, ${ }^{5}$ 倉 林 正 彦 ${ }^{1}$
}

\begin{abstract}
要 旨
【背景と目的】今回我々は，経皮エストラジオール及び経口結合型エストロゲンが閉経後女性の脈波伝播速 度, 皮膚弾力性及び骨密度に与える影響を比較検討した。【対象と方法】 経皮エストラジオールを投与する 群 (経皮群, 26 例), 経口結合型エストロゲンを投与する群 (経口群, 17 例), 希望により HRT を行わない群 (コ ントロール群, 23 例) の 3 群に分類し, 12 力月間行った. 試験開始前及び 12 力月後に脈波伝播速度, 皮膚弾力 性, 骨密度を測定した。【結 果】 経口群及びコントロール群の脈波伝播速度は変化しなかったが，経皮群 の脈波伝播速度は有意に減少した $(\mathrm{p}<0.05)$. 皮膚弾力性及び骨密度は，経皮群 $(\mathrm{p}<0.05, \mathrm{p}<0.01)$ ，経口群 $(\mathrm{p}<0.01, \mathrm{p}<0.01)$ ともにそれぞれ有意に増加したが，コントロール群では皮膚弾力性は変化せず，逆に骨密 度は有意に減少した $(\mathrm{p}<0.01)$ 。【結 語】閉経後女性に対する経皮エストラジオールは経口結合型エスト ロゲンょりも心血管系に有益であり，両治療とも皮膚の若返りや骨の強化に有効であると思われる。(Kita-
\end{abstract} kanto Med J 2006；56：119〜127)

キーワード : エストロゲン, 閉経後女性, 動脈硬化, 皮膚の弾力性, 骨密度

は じめに

女性は閉経を迎えると更年期障害が出現し，さらに骨 粗鬆症, 動脈硬化性疾患, 皮膚の変性, 老年痴呆, うつな ぞの老年疾患が増加する．これは加齢に加えエストロゲ ンの欠乏が原因と考元られている. エストロゲン受容体 が骨, 血管, 皮膚, 脳, 心臟等の多臟器に存在するため, こ れらの治療，予防にはエストロゲンによるホルモン補充 療法 (hormone replacement therapy：HRT) が有効であ ると考元られている.しかし, 最近の欧米での大規模臨 床研究 Women's Health Initiative (WHI) 1,2 亿扔いて, 経 口 HRT は骨折の予防には有効であったが, 心血管病の 発症を増加させた。この機序の一部として, 経口結合型 エストロゲン (conjugated equine estrogen : CEE) が肝 臟の初回通過効果によって, 動脈硬化性疾患の危険因子 である血中高感度 C 反応性蛋白 (high-sensitivity C -reactive protein: hs-CRP) やトリグリセリドを上昇さ せたことが考えられる. ${ }^{3}$ 最近開発された経皮エストラジ オール (estradiol：E2) は, 肝臟での初回通過効果を受け ずに血中 hs-CRP やトリグリセリドの上昇を抑制す

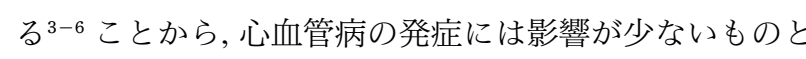
推測される. そこで, 今後の HRT は経皮 E2 が主流に なっていくものと思われるが，我が国女性に対する経皮 E2 の動脈硬化, 皮膚及び骨組織への効果については不明 である.

動脈硬化度, 皮膚の変性, 骨粗鬆症の簡便な評価法と して上腕一足関節部脈波伝播速度 (brachial-ankle pulse wave velocity：baPWV), 上腕部中間部の皮膚の弾力性, 腰椎 (lumbar : L) ${ }^{2-4}$ の骨密度 (bone mineral density: BMD) の測定がそれぞれ存在する. baPWV は年齢とと もに上昇し, 7 皮膚の弾力性及び骨密度は年齢とともに低 下すると報告 $8-10$ されている. 我々は, これまでに閉経後

1 群馬県前橋市昭和町3-39-22 群馬大学大学院医学系研究科臟器病態内科学 $\quad 2$ 群馬県渋川市北橘町下箱田740 北関東循環器 病院内科 3 群馬県高崎市中大類町501 高崎健康福祉大学看護学部 4 群馬県前橋市昭和町3-39-22 群馬大学大学院医学系 研究科病態検查医学 5 群馬県前橋市昭和町3-39-15 群馬大学医学部附属病院医療情報部

平成18年 2 月 8 日 受付

論文別刷請求先 干370-0033 群馬県高崎市中大類町501 高崎健康福祉大学看護学部 角野博之 
女性に対する経口 CEE が baPWV を減少させ ${ }^{3}$ 皮膚の 弾力性を上昇させ ${ }^{8}$ BMD を増加させることを報告して きた. 経皮 $\mathrm{E} 2$ が経口 CEE よりも有効で有害事象が少な ければ, 閉経後女性の治療として経皮 E2 の使用頻度が 増すものと推測される。，今回我々は，経皮 E2 が経口 CEE に比べ baPWV，皮膚の弾力性及び BMD に対して 有効であるか否かを比較するため, 閉経後女性に対して 経皮 $\mathrm{E} 2$ 及び経口 CEE を投与し，それらに与える影響を 検討した。

\section{対象と方法}

\section{対 象}

2001 年から 2005 年までの期間, 北関東循環器病院に 通院している更年期症状または骨粗鬆症を有する閉経後 女性のうち，同意の得られた 66 例（平均年齢 $57.3 \pm 7.1$ 歳, 45 歳-75 歳) を対象とした.すべての女性は子宮を持 ち, 閉経後 1 年以上を経過していた，皮膚病，糖尿病，重 症高血圧症, 心血管病, 腎不全, 悪性腫瘍, 肝疾患, 血栓塞 栓症, HRT 施行中及び使用歴のある患者は除外した。高 血圧症，高脂血症患者は同院で少なくとも 3 年以上降圧 治療, コレステロール低下治療をそれぞれ受けており， 研究期間中は投薬内容を変えなかった。

\section{プロトコール}

我久は閉経後女性を, 患者の希望により経皮 E2 を投 与する群 (経皮 $\mathrm{E} 2$ 群, 26 例), 経口 CEE を投与する群 (経口 CEE 群, 17 例), HRT を行わない群 (コントロール 群, 23 例) の 3 群に分類した. 経皮 E2 群は連続的 E2 (工 ストラダーム $\left.\mathrm{M}^{\circledR}\right)(36 \mu \mathrm{g} /$ 日) と周期的䤀酸メドロキシプ ロゲステロン (medroxyprogesterone acetate : MPA) (プ ロベラ®) $(2.5 \mathrm{mg} /$ 日, 12 日間/月) の併用投与を 12 力月間 行った.一方, 経口 CEE 群は連続的 CEE (プレマリン®) $(0.625 \mathrm{mg} /$ 日) と周期的 MPA (プロベラ®) $(2.5 \mathrm{mg} /$ 日, 12 日間/月) の併用投与を 12 カ月間行った.コントロール群 では 12 カ月間の経過観察を行った. 試験開始前及び 12 力月後, 外来にて身長, 体重, 血圧, 心拍数, baPWV, 皮膚 の弾力性, BMD の測定, 採血にて血清卵胞刺激ホルモン (follicle-stimulating hormone: FSH), E2, hs-CRP, 総コ レステロール，高比重リポタンパク (high-density lipoprotein：HDL) コレステロール，トリグリセリド，低比 重リポタンパク (low-density lipoprotein：LDL) コレス テロール, 尿酸の測定を行った。

\section{baPWV の測定}

被検者はベッド上で 10 分間の安静を保つ. その後, 上 腕一足首部間の脈波伝播速度 (pulse wave velocity： PWV) を form PWV/ABI (日本コーリン社製, Komaki,
Japan）を用いて測定した. 3,7

\section{皮膚の弾力性測定}

座位にて 10 分間以上安静にした被検者の右前腕中間 部に, キュトメーターSEM474 (Courage and Khazaka Electronic 社製, Koeln, Germany) に連結した吸引プ ローべを当て, 吸引した時に皮膚が伸びた距離と吸引を 解除した後の皮膚の戻った距離を測定し求めた. 9,10

皮膚の弾力性 $(\%)=$ 吸引を解除した後の皮膚の戻つ た距離/吸引した時に皮膚が伸びた距離 $\times 100(\%)$

\section{骨密度測定}

腰椎 L2 から L4 の BMD は被検者を背臥位にし, dual X-ray absorptiometry (DXA; QDR-1000W, Hologic, Waltham, USA) を用いて, BMD を測定した. ${ }^{10}$

\section{血液測定}

血清 FSH と血清 E2 はラジオイムノアッセイ法にて 測定した. hs-CRP はベーリングBNII ネフェロメー ター (Dade Boering, Mannheim, Germany) にて測定し た. 血清総コレステロール，HDL コレステロール，トリ グリセリド，血清尿酸值は酵素法にて測定した．LDL コ レステロールは Friedewald の式を用いて算出した.

\section{倫 理}

本研究は北関東循環器病院の倫理委員会において承認 され (No. 2002), 患者の同意を得た。

\section{統計解析}

3 群間の得られた值の比較は一元配置分散分析, 3 群 間での割合の比較は $\chi^{2}$ 検定, 各群の前と 12 力月後の值 の比較は $\mathrm{t}$-検定にてそれぞれ解析を行った. 各群の值 は平均土標準偏差で表記し, $\mathrm{p}$ 值が 0.05 未満を有意差あ りとした。すずての統計解析は, SPSSソフトウェア (ヴァージョン 11.0) を使用した.

\section{結果}

\section{患者背景及び血圧, ホルモンの变化}

試験開始前に 3 群の間で年齢, 身長, 体重, 喫煙者・高 血圧症・降圧薬・高脂血症・コレステロール低下薬の割 合に有意差を認めなかった (表 1). 全ての群において, 血 圧及び心拍数は試験開始前に比べ 12 力月後に有意な変 化を示さなかった。経皮 $\mathrm{E} 2$ 群及び経口 CEE 群におい て, 12 カ月後の FSH は試験開始前に比べそれぞれ有意 に減少し $(\mathrm{p}<0.01, \mathrm{p}<0.01)$, 反対に E2 はそれぞれ有意 に増加した $(\mathrm{p}<0.01, \mathrm{p}<0.01)$. コントロール群において は，E2 及び FSH はそれぞれ有意に変化しなかった。こ 
Table 1 Clinical characteristics

\begin{tabular}{lccc}
\hline & Transdermal E2 & Oral CEE & Control \\
\hline $\mathrm{n}$ & 26 & 17 & 23 \\
Age (years) & $55.7 \pm 6.7$ & $56.6 \pm 6.5$ & $59.7 \pm 7.5$ \\
Height (m) & $1.55 \pm 0.06$ & $1.54 \pm 0.06$ & $1.53 \pm 0.06$ \\
Weight (kg) & $51.9 \pm 7.5$ & $54.9 \pm 7.5$ & $54.2 \pm 12.4$ \\
Smokers (n) & 2 & 1 & 2 \\
Hypertension (n) & 9 & 7 & 9 \\
Antihypertensive drugs & & & 2 \\
ACE inhibitors (n) & 2 & 2 & 2 \\
ARBs (n) & 3 & 2 & 1 \\
$\quad \alpha$ l-blockers (n) & 1 & 1 & 2 \\
$\beta$-blockers (n) & 2 & 2 & 3 \\
Calcium antagonists (n) & 3 & 3 & 1 \\
Diuretics (n) & 1 & 1 & 7 \\
Hyperlipidemia (n) & 8 & 7 & 3 \\
Cholesterol-lowering drugs & & 3 & 1 \\
Statins (n) & 4 & 0 & \\
Fibrates (n) & 1 & 3 & \\
\hline
\end{tabular}

Mean \pm SD E2 : estradiol, CEE : conjugated equine estrogen, ACE : angiotensin-converting enzyme, ARBs : angiotensin II receptor blockers

Table 2 Changes in blood pressure and serum levels of hormone, hs-CRP, lipids, and uric acid

\begin{tabular}{|c|c|c|c|}
\hline & Transdermal E2 & Oral CEE & Control \\
\hline \multicolumn{4}{|c|}{ Systolic blood pressure $(\mathrm{mmHg})$} \\
\hline Baseline & $123.7 \pm 13.7$ & $136.7 \pm 12.6$ & $132.9 \pm 10.8$ \\
\hline 12 months & $120.5 \pm 14.5$ & $133.5 \pm 11.6$ & $132.4 \pm 12.7$ \\
\hline \multicolumn{4}{|c|}{ Diastolic blood pressure $(\mathrm{mmHg})$} \\
\hline Baseline & $77.2 \pm 8.3$ & $82.5 \pm 6.9$ & $82.3 \pm 8.1$ \\
\hline 12 months & $74.8 \pm 7.2$ & $83.8 \pm 3.6$ & $84.2 \pm 7.1$ \\
\hline \multicolumn{4}{|c|}{ Heart rate (beats/min) } \\
\hline Baseline & $63.9 \pm 5.4$ & $59.8 \pm 4.6$ & $64.9 \pm 6.3$ \\
\hline 12 months & $64.3 \pm 4.4$ & $59.4 \pm 4.2$ & $64.5 \pm 5.4$ \\
\hline \multicolumn{4}{|c|}{ FSH $(\mathrm{mIU} / \mathrm{ml})$} \\
\hline Baseline & $65.0 \pm 16.8$ & $67.2 \pm 16.8$ & $63.8 \pm 16.0$ \\
\hline 12 months & $23.5 \pm 9.8^{* *}$ & $24.5 \pm 12.9^{* *}$ & $63.2 \pm 14.3$ \\
\hline \multicolumn{4}{|c|}{ Estradiol (pg/ml) } \\
\hline Baseline & $13.7 \pm 2.7$ & $12.3 \pm 2.8$ & $13.2 \pm 5.9$ \\
\hline 12 months & $81.3 \pm 20.6^{* *}$ & $75.9 \pm 20.7^{* *}$ & $13.0 \pm 3.1$ \\
\hline \multicolumn{4}{|c|}{$\mathrm{hs}^{-} \mathrm{CRP}(\mathrm{ng} / \mathrm{ml})$} \\
\hline Baseline & $45.0 \pm 51.8$ & $63.4 \pm 68.2$ & $53.2 \pm 52.0$ \\
\hline 12 months & $37.5 \pm 45.8$ & $159.1 \pm 189.7^{* *}$ & $53.8 \pm 48.7$ \\
\hline \multicolumn{4}{|c|}{ Total cholesterol $(\mathrm{mg} / \mathrm{dl})$} \\
\hline Baseline & $215.9 \pm 32.6$ & $207.8 \pm 32.5$ & $204.9 \pm 30.4$ \\
\hline 12 months & $210.5 \pm 32.7$ & $190.2 \pm 23.5^{* *}$ & $203.1 \pm 31.3$ \\
\hline \multicolumn{4}{|c|}{ HDL-cholesterol (mg/dl) } \\
\hline Baseline & $58.5 \pm 10.7$ & $61.6 \pm 13.3$ & $62.5 \pm 15.2$ \\
\hline 12 months & $60.6 \pm 16.6$ & $63.4 \pm 10.5$ & $59.8 \pm 13.9$ \\
\hline \multicolumn{4}{|c|}{ Triglyceride $(\mathrm{mg} / \mathrm{dl})$} \\
\hline Baseline & $91.9 \pm 40.4$ & $110.9 \pm 44.4$ & $107.8 \pm 58.4$ \\
\hline 12 months & $99.3 \pm 57.4$ & $129.8 \pm 55.9^{*}$ & $103.0 \pm 60.0$ \\
\hline \multicolumn{4}{|c|}{ LDL-cholesterol $(\mathrm{mg} / \mathrm{dl})$} \\
\hline Baseline & $139.0 \pm 31.3$ & $124.0 \pm 27.3$ & $120.8 \pm 28.4$ \\
\hline 12 months & $130.1 \pm 26.6$ & $100.8 \pm 20.0^{* *}$ & $122.7 \pm 25.5$ \\
\hline \multicolumn{4}{|c|}{ Uric acid (mg/dl) } \\
\hline Baseline & $4.8 \pm 1.4$ & $5.0 \pm 1.1$ & $5.0 \pm 1.1$ \\
\hline 12 months & $4.4 \pm 1.1^{*}$ & $4.6 \pm 1.0^{*}$ & $5.0 \pm 1.1$ \\
\hline
\end{tabular}

Mean $\pm \mathrm{SD} * \mathrm{p}<0.05,{ }^{*} \mathrm{p}<0.01$ vs. baseline

E2 : estradiol, CEE : conjugated equine estrogen, FSH : follicle-stimulating hormone, hs-CRP : high-sensitivity C-reactive protein, HDL : high-density lipoprotein, LDL : low-density lipoprotein 


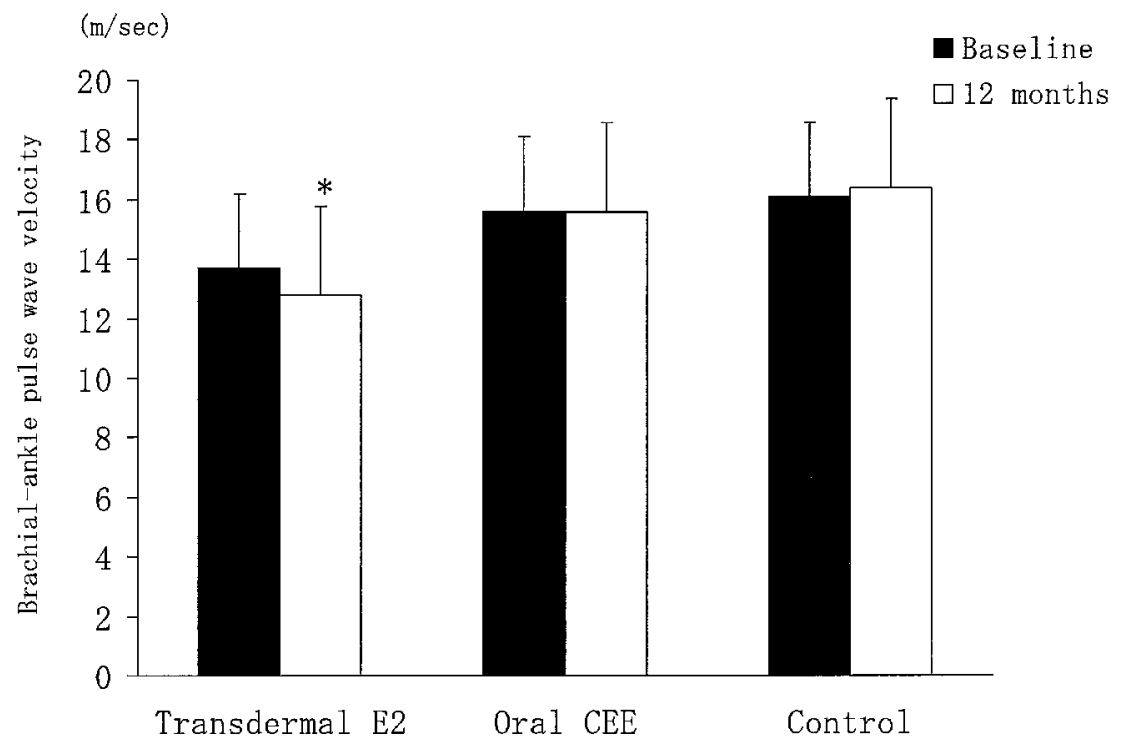

Fig.1 Changes in brachial-ankle pulse wave velocity ${ }^{*} \mathrm{p}<0.05$ vs. baseline E2: estradiol, CEE : conjugated equine estrogen

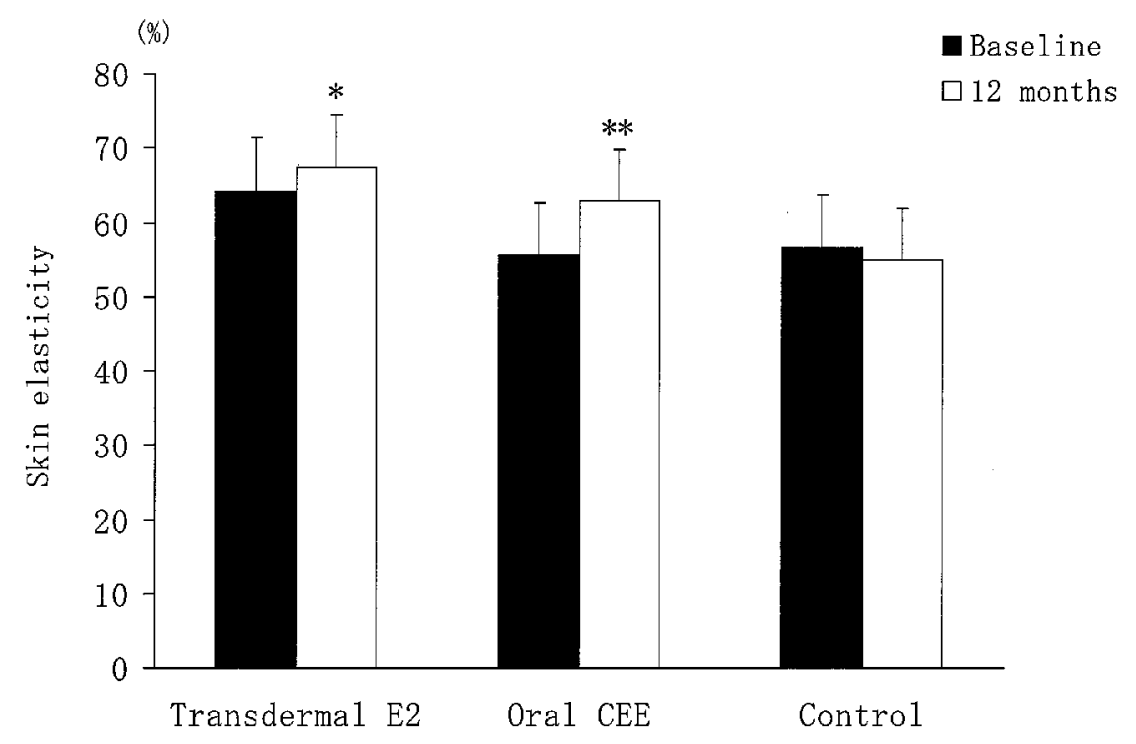

Fig.2 Changes in skin elasticity ${ }^{*} \mathrm{p}<0.05,{ }^{*} \mathrm{p}<0.01$ vs. baseline E2: estradiol, CEE : conjugated equine estrogen

のことは, 経皮 E2 群及び経口 CEE 群においては，エス トロゲン剤の服薬コンプライアンスが良好であったこと を示していた (表 2).

\section{hs-CRP 蛋白, 脂質及び尿酸の変化}

hs-CRP は，経口 CEE 群において試験開始前に比べ 12 力後に有意に増加し $(\mathrm{p}<0.01)$, 経皮 E2 群及びコン トロール群においてはそれぞれ有意な変化を示さなかっ た. 血清脂質については, 経口 CEE 群の総コレステロー ル及び LDL コレステロールの值は試験開始前に比べ 12 月後にそれぞれ有意に減少し $(\mathrm{p}<0.01, \mathrm{p}<0.01)$, 卜 リグリセリドの值は試験開始前に比べ 12 力月後に有意 に増加した $(\mathrm{p}<0.05)$ が, HDL コレステロールは有意に 変化しなかった. 経皮 $\mathrm{E} 2$ 群及びコントロール群におい
ては, 総コレステロール, HDL コレステロール，トリグ リセリド, LDL コレステロールの值は試験開始前に比べ 12 月後にそれぞれ有意に変化しなかった. 血清尿酸值 は, 経皮 E2 群及び経口 CEE 群において試験開始前に比 べ12カ月後にそれぞれ有意に低下した $(\mathrm{p}<0.05, \mathrm{p}<$ 0.05). コントロール群においては変化しなかった (表 2).

\section{baPWV の変化}

baPWV については, 経口 CEE 群及びコントロール群 の值は試験開始前に比べ 12 力後にそれぞれ有意な変 化を示さなかったが, 経皮 E2 群の值は試験開始前 $13.7 \pm 3.0 \mathrm{~m} /$ 秒から 12 力月後 $12.8 \pm 2.5 \mathrm{~m} /$ 秒に有意に減 少した $(\mathrm{p}<0.05)$ (図 1$)$. 


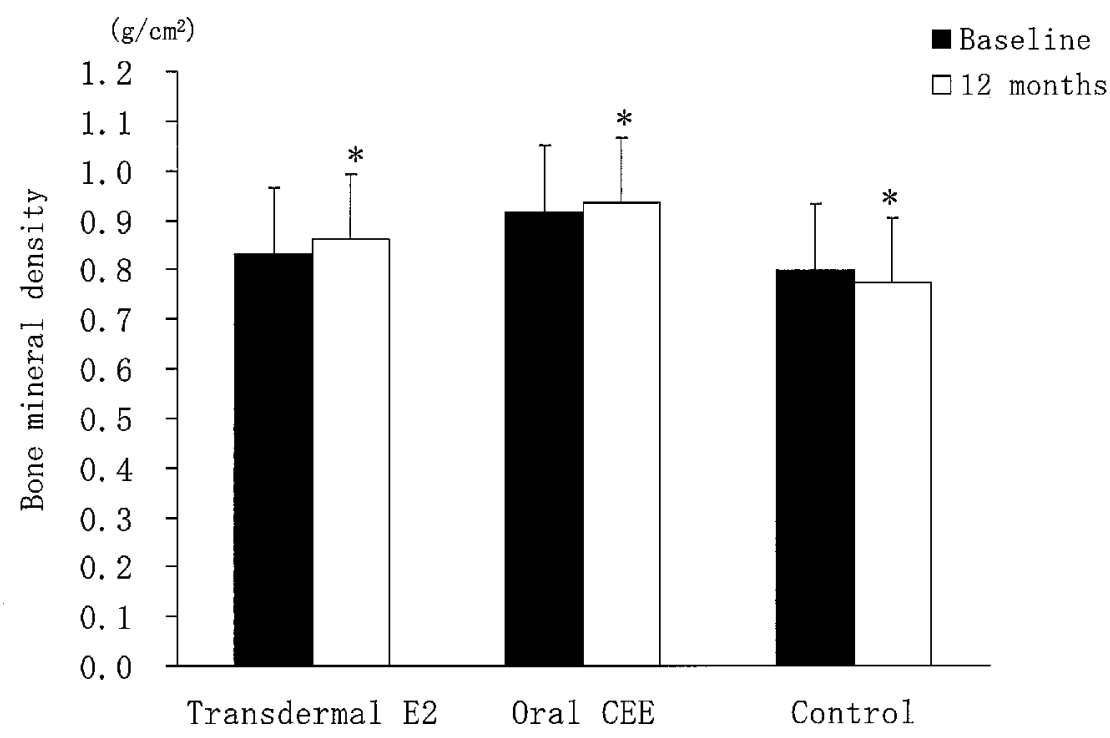

Fig.3 Changes in bone mineral density ${ }^{*} \mathrm{p}<0.01$ vs. baseline E2: estradiol, CEE : conjugated equine estrogen

\section{皮膚の弾力性の変化}

皮膚の弾力性は，経皮 E2 群及び経口 CEE 群におい て, 12 カ月後の值は試験開始前に比べそれぞれ有意に増 加した $(\mathrm{p}<0.05, \mathrm{p}<0.01)$ が. コントロール群においては 有意な変化を示さなかった (図 2).

\section{$\mathrm{BMD}$ の変化}

BMD に関しては，経皮 E2 群及び経口 CEE 群におい て，12力月後の值は試験開始前に比べそれぞれ有意に増 加した $(\mathrm{p}<0.01, \mathrm{p}<0.01)$ が, 反対にコントロール群にお いては 12 力月後の值は試験開始前に比べ有意に減少し た $(\mathrm{p}<0.01)$ (図 3).

\section{考}

察

本研究では, 経皮 E2 は経口 CEE と異なり, 閉経後女 性の血清 hs-CRP やトリグリセリドを上昇させず, baPWV を増加させた。 また，経皮 E2 は経口 CEE と同 様に, 血清尿酸, 皮膚の弾力性及び BMD を増加させた。

経皮 $\mathrm{E} 2$ 及び経口 CEE 投与が閉経後女性の PWV に 与える影響について，いくつかの報告 ${ }^{11-14}$ がある. 経皮 $\mathrm{E} 2$ 亿関して，12力月間の経皮 $\mathrm{E} 250 \mu \mathrm{g}$ と経口酢酸ノル エチステロンの連日併用投与が，高血圧症閉経後女性の 頸動脈一大腿動脈間の PWV を減少させた. ${ }^{11}$ また, Ganger ら ${ }^{12}$ は 22 週間の経皮 E2 $50 \mu \mathrm{g}$ 連日と周期的経口 MPA $10 \mathrm{mg} /$ 日の併用投与が, 閉経後女性の内頸動脈の低 下した血流や血管張力を改善することを報告した。これ らの変化は血圧による影響を受けていなかった。一方, Westendorp ら ${ }^{13}$ は2 24 力月間の連日経口 CEE0.625mg/ 日と周期的ノルゲストレル $0.15 \mathrm{mg} /$ 日 (12 日間/月) の併 用投与は, 閉経後女性の頸動脈の伸展性には影響を与え
ないことを報告した.さらに, 2 型糖尿病の肥満閉経後女 性に扔いて,6力月間の経口 CEE0.625mg と MPA5mg の 連日併用投与は大動脈一大腿動脈の PWV を変化させな かった. ${ }^{14}$ エストロゲンやプロゲステロンの量・種類・投 与法・期間, PWV の評価法等の相違が存在するものの, それらの報告は本研究の結果と同様である.したがって, 経口 CEE とは異なり, 経皮 E2 投与は動脈硬化度に対し て有効である可能性がある。

BaPWV は血圧值と正の相関関係を示す. ${ }^{7}$ 血圧值が高 いほど，baPWV は高値となることから，baPWV は血圧 の值に強く影響を受ける. 本研究において経皮 $\mathrm{E} 2$ 及び 経口 CEE ともに血圧を変化させなかった.この結果は 我々の以前発表した報告3,5,6,15-23 と一致する。 このよう に，HRT に使用するエストロゲン鼡では血圧に対する 効果はかなり少なく， 経皮 $\mathrm{E} 2$ が血圧への影響を介して baPWV を変化させている可能性は少ない，

CRP や他の炎症性マーカーは動脈硬化形成にとって 重要な役割を果たしている. ${ }^{24}$ 臨床研究において，経口 CEE 投与は閉経後女性の血中 CRP を上昇させる ${ }^{3,25}$ が, 経皮 E2 の投与は CRP を上昇させない. ${ }^{3,4}$ また, HRT と 血清脂質に関する報告では, 経口 CEE 投与は閉経後女 性の血清総コレステロールや LDL コレステロールを低 下させ，トリグリセリドや HDL コレステロールを上昇 させる. ${ }^{3,26-31}$ 一方, 経皮 $\mathrm{E} 2$ 投与は血清脂質を変化させ ない. $3,5,6$ 本研究においても血清 $\mathrm{hs}^{-} \mathrm{CRP}$ 及び脂質に対し て同様な結果を得た. 経口 $\mathrm{CEE}$ と経皮 $\mathrm{E} 2$ の hs-CRP と 脂質への差異の理由として, 経口 CEE は肝臟の初回通 過効果を介するため hs-CRP 及びトリグリセリドの上 昇を招くが, 経皮 E2 は肝臟の初回通過効果が減弱して いるため hs-CRP 及び脂質への影響は少ないことが推 
測される.

HRT と血清尿酸值に関して, 経口 CEE は高尿酸血症 を有する閉経後女性の血清尿酸值を低下させる. ${ }^{32}$ 本研 究においても経口 CEE 及び経皮 E2 は閉経後女性の血 清尿酸值を低下させた. その機序の一つとして, エスト ロゲンによる尿中からの尿酸排泄量の増加が考えられ る. ${ }^{33}$

経皮 $\mathrm{E} 2$ 及び経口 CEEによる PWV に対する結果が 異なった理由については不明であるが, 2 つ機序を推 測することができる. 第一に，エストロゲン受容体は血 管平滑筋や線維芽細胞に存在し，エストロゲンにより動 物レベルの線維芽細胞の成長やコラーゲン合成が抑制さ

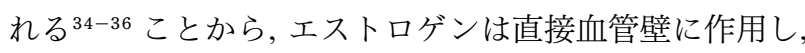
血管壁の肥厚を抑えるものと考えられる，ところが，E2 と CEE を比較してみると, $17 \beta-\mathrm{E} 2$ は天然型ホルモンで あるが, CEE は妊娠馬尿から得られたホルモンであり， 少なくとも 10 種類の結合型エストロゲンを含んでおり， その中にはヒト女性には存在しないエストロゲンがいく つか存在する. ${ }^{37} さ ら に, C E E$ はアンドロゲンやプロゲ ステロンも含んでいる. ${ }^{38}$ アンドロゲンは女性から男性 への性転換者の前腕動脈の内皮依存性血管拡張反応を減 弱させるとの報告 ${ }^{39}$ がある. よって, E2 は CEEよりも 血管に対して有効であるものと思われる. 第二に, 本研 究では経口 CEE 投与は閉経後女性の hs-CRP やトリグ リセリドを増加させた. 経口 CEE 投与によるそれらの 増加が心血管病の発症に関与する LDL コレステロール の小型化を惹起させ ${ }^{40}$ LDL コレステロールの低下や HDL コレステロールの上昇などの有益な作用を相殺し， baPWVの減少を招かなかった可能性が考えられる.

老化した皮膚は, シワが多く, 真皮のコラーゲンが減 少し, 創傷治癒力がそしい. ${ }^{41}$ 光・電子顕微鏡により評価 した真皮の加齢変化は, コラーゲン繊維束の減少にとも なう弾性線維網の重度の崩壊である. ${ }^{42}$ エラスチンやコ ラーゲンのような真皮構成物の変化は, 皮膚の厚み ${ }^{43} や$ 弾力性の変化 ${ }^{9}$ に関連している. Brincat $ら^{43}$ は, 閉経後年 数と右大腿部から採取した皮膚のコラーゲン成分や前腕 の皮膚の厚みとそれぞれ負の相関関係があることを述べ た.また, Castelo-Branco ら ${ }^{44}$ は皮膚真皮のコラーゲン 成分は 20 歳から 40 歳でピークを示し, 40 歳から 60 歳 で減少することを報告した. 我々も年齢や閉経後年数の 増加，エストロゲン濃度の減少によって皮膚の弾力性が 低下することを報告8,10 した。ゆえに，閉経前女性の皮膚 の老化は年齢と関係するが, 閉経を迎えると低エストロ ゲン状態が加わり，皮膚真皮のコラーゲン成分などの低 下にともなって皮膚弾力性の低下が加速するものと思わ れる，一方，エストロゲンはコラーゲン成分及び皮膚の 厚みを増加させる ${ }^{45,46}$ ため, 吸引装置を用いた前腕部の
皮膚弾性を評価した研究において, 経皮 E2 (50 $\mu \mathrm{g} /$ 日) と経皮プロゲステロンの連続併用投与 ${ }^{47}$ 及び連続的経口 CEE $(0.625 \mathrm{mg} /$ 日) と周期的経ロプロゲステロンの併用 投与 ${ }^{8,48}$ は皮膚の弾力性を増加させる. これらの報告は本 研究の結果を支持する.したがって, 低下した皮膚の弾 力性を有する閉経後女性の皮膚弾力性を改善する目的で 経皮 $\mathrm{E} 2$ 及び経口 CEE を投与すれば同様に有効な効果 が期待できるものと思われる。

閉経や去勢などによりエストロゲンが欠そした状態で はインターロイキン (interleukin: IL)-1, IL-6, tumor necrosis factor- $\alpha$ の産生が方進し, 骨破骨細胞の誘導が 促進され, 臨床的に高回転型の骨量減少を示す.エス卜 ロゲンは骨吸収を低下させ, 海面骨及び長管骨のいずれ の部位においてもそれらの骨量を増加させる.49 24 力月 間の経皮 E2 (0.025mg, 0.05mg, 0.06mg, 0.1 mg)の連日投 与は閉経後女性の腰椎 BMD をいずれの用量でも6力月 後より増加させた. ${ }^{50}$ また, 36 カ間の連続的経口 CEE $(0.625 \mathrm{mg} /$ 日) と連続的または周期的経口 MPA (2.5mg/ 日, 12 日間/月) の併用投与も閉経後女性の腰椎 BMD を いずれも 12 力月後より増加させた ${ }^{49} こ れ ら の$ 報告は, 本 研究の結果と一致する. このように, 経皮 $\mathrm{E} 2$ 及び経口 CEE ともに BMD 増加による骨強化に有効であり, 骨折 の予防効果が期待できる.

本研究では, 経皮 E2 は経口 CEE と異なり, 閉経後女 性の動脈硬化度を改善し, hs-CRP やトリグリセリドの 増加を認めなかった。 また, 経皮 E2 は経口 CEE と同様 に, 血清尿酸, 皮膚の弾力性及び骨密度を増加させた。 こ のように，経皮 E2 は経口 CEE に比べ，心血管病に対し て有害事象が少なく有益である可能性を有する。また, 経皮 E2 は経口 CEE と同等に皮膚の若返りに伴う美容 及び骨強化による骨折予防に伴う生活の質向上の達成に 有効であると思われる。しかし，エストロゲン剤は投与 の仕方によっては閉経後女性の健康増進に有効であるも のの, 一方で乳癌, 脳卒中及び血栓症の発症が増加する 可能性も否定できない. 今後, エストロゲン剤の有効性 及び危険性について検討した我が国の大規模臨床試験の 結果が待たれる.

\section{謝辞}

本研究にご協力をいただきました北関東循環器病院の 関係職員各位に深く感謝いたします。

なお, 本研究は 2004 年度財団法人総合健康推進財団 研究奨励助成 (角野博之), 2001～2003 年度厚生労働省長 寿科学総合研究事業助成 (市川秀一) 及び 2003 2005 年 度財団法人長寿科学振興財団長寿医療研究委託事業助成 (市川秀一) の一部により遂行された. 


\section{文献}

1. Writing Group for the Womens Health Initiative Investigators. Risks and benefits of estrogen plus progestin in healthy postmenopausal women: Principal results from the Womens Health Initiative randomized controlled trial. JAMA 2002; $288: 321-333$.

2. Womens Health Initiative Steering Committee. Effects of conjugated equine estrogen in postmenopausal women with hysterectomy. The Womens Health Initiative Randomized Controlled Trial. JAMA 2004; 291: 1701 -1712 .

3. Sumino $\mathrm{H}$, Ichikawa $\mathrm{S}$, Kasama $\mathrm{S}$, et al. Different effects of oral conjugated estrogen and transdermal estradiol on arterial stiffness and vascular inflammatory markers in postmenopausal women. Atherosclerosis (in press)

4. Decensi A, Omodei U, Robertson C, et al. Effect of transdermal estradiol and oral conjugated estrogen on $\mathrm{C}$ -reactive protein in retinoid-placebo trial in healthy women. Circulation 2002; 106: 1224-1228.

5. Sumino $\mathrm{H}$, Ichikawa $\mathrm{S}$, Ohyama $\mathrm{Y}$, et al. Effect of transdermal hormone replacement therapy on the monocyte chemoattractant protein -1 concentrations and other vascular inflammatory markers and on endothelial function in postmenopausal women. Am J Cardiol $2005 ; 96$ : 148-153.

6. Sumino $\mathrm{H}$, Ichikawa $\mathrm{S}$, Kasama $\mathrm{S}$, et al. Effect of transdermal hormone replacement therapy on carotid artery wall thickness and levels of vascular inflammatory markers in postmenopausal women. Hypertens Res $2005 ; 28$ : 579-584.

7. Yamashina A, Tomiyama H, Takeda K, et al. Validity, reproducibility, and clinical significance of noninvasive brachial-ankle pluse wave velocity measurement. Hypertens Res $2002 ; 25$ : 359-364.

8. Sumino H, Ichikawa $\mathrm{S}, \mathrm{Abe} \mathrm{M}$, et al. Effects of aging, menopause, and hormone replacement therapy on forearm skin elasticity in women. J Am Geriatr Soc 2004; 52 : 945-949.

9. Ishikawa T, Ishikawa O, Miyachi Y. Measurement of skin elastic properties with a new suction device (I) : Relationship to age, sex and the degree of obesity in normal individuals. J Dermatol 1995; 22: 713-717.

10. Sumino H, Ichikawa $\mathrm{S}$, Abe M, et al. Effects of aging and postmenopausal hypoestrogenism on skin elasticity and bone mineral density in Japanese women. Endocr $\mathbf{J}$ 2004; $51:$ 159-164.

11. Kawecka-Jaszcz K, Czarnecka D, Olszanecka A, et al. The effect of hormone replacement therapy on arterial blood pressure and vascular compliance in postmenopausal women with arterial hypertension. J Hum Hypertens $2002 ; 16$ : 509-516.

12. Gangar KF, Vyas S, Whitehead M, et al. Pulsatility index in internal carotid artery in relation to transdermal oestradiol and time since menopause. Lancet 1991; $338: 839-842$.

13. Westendorp IC, de Kleijn MJ, Bots ML, et al. The effect of hormone replacement therapy on arterial distensibility and compliance in perimenopausal women: a 2-year randomised trial. Atherosclerosis $2000 ; 152$ : 149-157.

14. Samaras K, Hayward CS, Sullivan D, et al. Effects of postmenopausal hormone replacement therapy on central abdominal fat, glycemic control, lipid metabolism, and vascular factors in type 2 diabetes: a prospective study. Diabetes Care 1999; 22: 1401-1407.

15. Sumino $\mathrm{H}$, Ichikawa $\mathrm{S}$, Kanda $\mathrm{T}$, et al. Hormone replacement therapy in postmenopausal women with essential hypertension increases circulating plasma levels of bradykinin. Am J Hypertens 1999; 12 : 1044-1047.

16. Umeda $\mathrm{M}$, Ichikawa $\mathrm{S}$, Kanda $\mathrm{T}$, et al. Hormone replacement therapy increases plasma level of angiotensin II in postmenopausal hypertensive women. Am J Hypertens 2001; 14: 206-211.

17. Nogawa N, Sumino H, Ichikawa S, et al. Effect of long -term hormone replacement therapy on angiotensin -converting enzyme activity and bradykinin in postmenopausal women with essential hypertension and normotensive postmenopausal women. Menopause 2001; $8: 210-215$.

18. Miya Y, Sumino H, Ichikawa S, et al. Effects of hormone replacement therapy on left ventricular hypertrophy and growth-promoting factors in hypertensive postmenopausal women. Hypertens Res 2002 ; 25 : 153-159.

19. Sumino H, Ichikawa S, Ohyama $\mathrm{Y}$, et al. Effects of hormone replacement therapy on serum angiotensin -converting enzyme activity and plasma bradykinin in postmenopausal women according to angiotensin-converting enzyme-genotype. Hypertens Res 2003 ; 26 : 53-58.

20. Sumino H, Ichikawa S, Kumakura H, et al. Effects of hormone replacement therapy on office and ambulatory blood pressure in Japanese hypertensive postmenopausal women. Hypertens Res $2003 ; 26$ : 369-376.

21. Tamama K, Sumino H, Ichikawa S, et al. Hormone replacement therapy causes a decrease in hepatocyte growth factor in hypertensive women. J Hypertens 2003 ; 21: 1151-1156.

22. Sumino H, Ichikawa S, Sawada Y, et al. Effects of hormone replacement therapy on blood coagulation and fibrinolysis in hypertensive and normotensive Japanese postmenopausal women. Thromb Res 2005; 115: 359 -366 .

23. Sumino H, Ichikawa S, Takahashi T, et al. Conjugated estrogen plus medroxyprogesterone does not impair blood rheological properties in hypertensive postmenopausal women. Maturitas 2006; 53 : 306-314.

24. Libby P. The interface of atherosclerosis and thrombosis : basic mechanisms. Vasc Med 1998; 3 : 225-229. 
25. Cushman M, Legault C, Barrett-Connor E, et al. Effect of postmenopausal hormones on inflammation-sensitive proteins : the Postmenopausal Estrogen/progestin Interventions (PEPI) Study. Circulation 1999; 100:717 -722 .

26. Writing Group for the PEPI Trial. Effects of estrogen or estrogen/progestin regimens on heart disease risk factors in postmenopausal women: the Postmenopausal Estrogen/ Progestin Intervention (PEPI) Trial. JAMA 1995; 273: 199-208.

27. Sumino H, Ichikawa S, Sakamoto H, et al. Effects of conjugated equine estrogen and medroxyprogesterone acetate on lipoprotein (a) and other lipoproteins in Japanese postmenopausal women with and without dyslipidemia. Horm Res 2004; 62: 1-9.

28. Sumino H, Nakamura $\mathrm{T}$, Ichikawa $\mathrm{S}$, et al. Serum level of vascular endothelial growth factor is decreased by hormone replacement therapy in postmenopausal women without hypercholesterolemia. Atherosclerosis 2000 ; 148: 189-195.

29. Sumino H, Ichikawa S, Murakami M, et al. Effects of hormone replacement therapy on circulating docosahexaenoic acid and eicosapentaenoic acid levels in postmenopausal women. Endocr J 2003; 50: 51-59.

30. Sumino H, Ichikawa S, Yoshida A, et al. Effects of hormone replacement therapy on weight, abdominal fat distribution, and lipid levels in Japanese postmenopausal women. Int J Obes Relat Metab Disord 2003； 27 : 1044 -1051 .

31. Sumino $\mathrm{H}$, Ichikawa $\mathrm{S}$, Itoh $\mathrm{H}$, et al. Hormone replacement therapy decreases insulin resistance and lipid metabolism in Japanese postmenopausal women with impaired and normal glucose tolerance. Horm Res 2003；60 : 134 -142 .

32. Sumino H, Ichikawa S, Kanda T, Nakamura T, Sakamaki T. Reductrion of serum uric acid by hormone replacement therapy in postmenopausal women with hyperuricaemia. Lancet 1999; $354: 650$.

33. Nicholls A, Snaith ML, Scott JT. Effect of oestrogen therapy on plasma and urinary levels. BMJ 1973; 1 : 449-451.

34. Beldekas JC, Gerstenfeld L, Sonenshein GE, et al. Cell density and estradiol modulation of procollagen type III in cultured calf smooth muscle cells. J Biol Chem 1982 ; 257: 12252-12256.

35. Fischer GM, Swain ML. Effects of estradiol and progesterone on the increased synthesis of collagen in atherosclerotic rabbit aortas. Atherosclerosis 1985; $54: 177$ -185 .

36. Dubey RK, Gillespie DG, Jackson EK, et al. 17Beta -estradiol, its metabolites, and progesterone inhibit cardiac fibroblast growth. Hypertension 1998; $31: 522$
-528 .

37. Bhavnani BR. Pharmacokinetics and pharmacodynamics of conjugated equine estrogens : chemistry and metabolism. Proc Soc Exp Biol Med 1998; $217: 6$ -16 .

38. Dey M, Lyttle RC, Pickar JH. Recent insights into the varying activity of estrogens. Maturitas 2000; 34 : S25 $-\mathrm{S} 33$.

39. McCredie RJ, McCrohon JA, Turner L, et al. Vascular reactivity is impaired in genetic females taking high-dose androgens. J Am Coll Cardiol 1998; 32: 1331-1335.

40. Wakatsuki A, Ikenoue N, Okatani Y, et al. Estrogen -induced small low density lipoprotein particles may be atherogenic in postmenopausal women. J Am Coll Cardiol 2001; 37: 425-30.

41. Uitto J. Connective tissue biochemistry of the aging dermis. age-related alterations in collagen and elastin. Dermatol Clin 1986 ; 4 : 433-446.

42. Braverman IM, Fonferko E. Studies in cutaneous aging: I. The elastic fiber network. J Invest Dermatol 1982; 78 : 434-443.

43. Brincat M, Kabalan S, Studd JW, et al. A study of the decrease of skin collagen content, skin thickness, and bone mass in the postmenopausal woman. Obstet Gynecol 1987; 70 : 840-845.

44. Castelo-Branco C, Pons F, Gratacos E, et al. Relationship between skin collagen and bone changes during aging. Maturitas 1994; 18 : 199-206.

45. Castelo-Branco C, Duran M, Gonzalez-Merlo J. Skin collagen changes related to age and hormone replacement therapy. Maturitas 1992; 15: 113-119.

46. Maheux R, Naud F, Rioux M, et al. A randomized, double-blind, placebo-controlled study on the effect of conjugated estrogens on skin thickness. Am J Obstet Gynecol 1994; 170 : 642-649.

47. Sator PG, Schmidt JB, Sator MO, et al. The influence of hormone replacement therapy on skin ageing: a pilot study. Maturitas 2001; 39: 43-55.

48. Pierard GE, Letawe C, Dowlati A, et al. Effect of hormone replacement therapy for menopause on the mechanical properties of skin. J Am Geriatr Soc 1995 ; 43: 662-665.

49. The Writing Group for the PEPI Trial. Effects of hormone therapy on bone mineral density: results from the postmenopausal estrogen/progestin interventions (PEPI) trial. JAMA 1996; 276: 1389-1396.

50. Weiss SR, Ellman H, Dolker M, for the transdermal estradiol investigator group. A randomized controlled trial of four doses of transdermal estradiol for preventing postmenopausal bone loss. Obstet Gynecol 1999; 94 : 330-336. 


\title{
Effects of Transderml and Oral Hormone Replacement Therapy on Atherosclerosis, Skin, and Bone in Postmenopausal Women
}

\author{
Hiroyuki Sumino, ${ }^{1}$ Shuichi Ichikawa, ${ }^{2}$ Hironosuke Sakamoto, ${ }^{3}$ \\ Masami Murakami, ${ }^{4}$ Tetsuo Sakamaki ${ }^{5}$ and Masahiko Kurabayashi ${ }^{1}$ \\ 1 Department of Medicine and Biological Science, Gunma University Graduate School of Medicine \\ 2 Department of Internal Medicine, Cardiovascular Hospital of Central Japan \\ 3 Department of Nursing, Takasaki University of Health and Welfare \\ 4 Department of Clinical Laboratory Medicine, Gunma University Graduate School of Medicine \\ 5 Medical Informatics and Decision Science, Gunma University Graduate School of Medicine
}

Background and Aims : We compared the effects of transdermal estradiol and oral conjugated equine estrogen on pulse wave velocity, skin elasticity, and bone mineral density in postmenopausal women. Methods : In a 12-month trial, 26 postmenopausal women (Transdermal group) received a transdermal estradiol, 17 (Oral group) received an oral conjugated equine estrogen, and 23 (Control group) did not receive either hormone. In each subject, we measured pulse wave velocity, skin elasticity, and bone mineral density before and 12 months after the start of the study. Results : In the oral and control groups, pulse wave velocity was not changed, but in the transdermal group, pulse wave velocity was significantly decreased. Skin elasticity and bone mineral density were significantly increased in the transdermal and oral groups, respectively. In the control group, however, skin elasticity was not changed and bone mineral density was significantly decreased. Conclusion: Transdermal estradiol may have a beneficial effect on cardiovascular system in postmenopausal women. Both hormonal therapy might be useful to an improvement in degenerated skin elasticity and an enhancement of bone mass. (Kitakanto Med J $2005 ; 55: 119 \sim 127)$

Key Words: Estrogen, Postmenopausal women, Atherosclerosis, Skin elasticity, Bone mineral density 